\title{
Properties of Bacillus species Cellulase Produced Using Cellulose from Brewers Spent Grain (BSG) as Substrate
}

\author{
Frank Anayo Orji1 ${ }^{*}$, Ekaette Nduka Dike1, Adekunle Kolawole Lawal1, \\ Abdulateef Omoniyi Sadiq2 ${ }^{2}$ Yewande Suberu' ${ }^{1}$, Ariyo Caleb Famotemi', \\ Agatha Isioma Ugbana1, Folake Fashola1, Blossom Ita1, Samuel Olakiitan Olatope1, \\ Emoleila Ejiya Itoandoan', Abimbola Olajumoke Adefiranye ${ }^{1}$, Gloria Nwakaegho Elemo ${ }^{3}$ \\ ${ }^{1}$ Department of Biotechnology, Federal Institute of Industrial Research, Oshodi (FIIRO), Ikeja, Nigeria \\ ${ }^{2}$ Department of Project Designs and Development, Federal Institute of Industrial Research, Oshodi (FIIRO), \\ Ikeja, Nigeria \\ ${ }^{3}$ Department of Food Technology, Federal Institute of Industrial Research, Oshodi (FIIRO), Ikeja, Nigeria \\ Email: *orjifa@yahoo.com, *anayo.orji@fiiro.gov.ng
}

Received 1 April 2015; accepted 13 March 2016; published 16 March 2016

Copyright @ 2016 by authors and Scientific Research Publishing Inc.

This work is licensed under the Creative Commons Attribution International License (CC BY).

http://creativecommons.org/licenses/by/4.0/

(c) (i) Open Access

\section{Abstract}

The properties of extracellular cellulase obtained from Bacillus species (FIIRO Strain B223) on supplying cellulose from Brewers Spent Grain (BSG) were studied. Generally, a crude cellulase activity between 11,757 Units to 13,930 Units was observed for both sources of carbon (BSG and crystalline cellulose). The optimum $\mathrm{pH}$ and temperature of 5.0 , and $30^{\circ} \mathrm{C}-40^{\circ} \mathrm{C}$ for both sources of carbon was observed. Heavy metals such as copper, zinc, and iron inhibited the activities of B223 cellulase while the cellulase activities on alkaline earth metal (manganese) were moderate. The co-factor behaviour of manganese ion was also established. Local production of cellulase in Nigeria using local raw materials such as Brewers Spent Grain reduces enzyme cost; cost of finished products and increases gross domestic products.

\section{Keywords}

Cellulase, Bacillus species, Crude Activities, Temperature, pH Tolerance, Brewers Spent Grains (BSG)

\section{Introduction}

There is an increasing interest in utilising cellulose wastes as feedstock for fermentation processes, thereby

${ }^{*}$ Corresponding author.

How to cite this paper: Orji, F.A., et al. (2016) Properties of Bacillus species Cellulase Produced Using Cellulose from Brewers Spent Grain (BSG) as Substrate. Advances in Bioscience and Biotechnology, 7, 142-148. 
converting low cost starting materials into products of greater value. Most commercial cellulases are produced by submerged fermentation of the fungi and bacteria [1]. Cellulose is mainly degraded by an enzyme known as cellulase. This is mainly produced by bacteria, fungi and protozoan that catalyse cellulolysis (i.e. hydrolysis) of cellulose. Cellulolytic microbes have important role in environment for degradation of cellulose and convert it into useful products [2]. Cellulases are mainly classified into 5 types on the basis of types of reaction catalyzedendo-cellulase: It breaks internal bond to disrupt crystalline structure of cellulose and expose individual cellulose polysaccharide chains. Exo-cellulase: this cleaves 2 - 4 units from the ends of exposed chains produced by endo-cellulase, resulting in the tetrasaccharide or disaccharide such as cellobiose.

There are 2 main types of exo-cellulases (cellobiohydrolases, abbreviate $\mathrm{CBH}$ - - one type working processively from the reducing end, and one type working processively from the non-reducing end. Processive/Progressive cellulase: This cellulase continues to interact with a single polysaccharide strand. Non-progressive/Non-Processive: This cellulase will interact once then disengages and engages another polysaccharide strand. Cellobiose/betagalactosidase: It hydrolyses the exo-cellulase product into individual monosaccharide. Oxidative cellulase: It depolymerises cellulose by radial reactions, as for instance cellobiose dehydrogenase (acceptor). Cellulose phosphorylases: It depolymerise cellulose using phosphate instead of water [3]. There are several research attempts to characterise different cellulase enzyme from different microorganisms based on temperature, $\mathrm{pH}$ and metallic ion interaction. Worldwide, cellulase as a commercial enzyme finds a lot of applications in Fruit juice clarification, cellulase assisted digestion in young ruminants (the cellulase is incorporated into animal feed), pulp and paper Industries, Breweries and bread industries, waste treatment industries etc. [4]. The properties of cellulase produced from microorganisms isolated from Archchartina marginata have previously been reported [4].

There is also report of effects of $\mathrm{pH}$, temperature, and metallic ions on cellulase produced from Streptomyces sp., using fruit waste as substrate. The several waste utilisation programmes all over the World are geared towards converting wastes to wealth. This study reports the use of cellulose from Brewers Spent Grain (BSG) waste for submerged production of cellulase, and the temperature, $\mathrm{pH}$, and metallic ion tolerance properties of the Bacillus cellulase.

\section{Materials and Methods}

\subsection{Isolation of Bacillus species}

The strain of choice was isolated from BSG undergoing bio-deterioration in the open environment. One (1) gram of the deteriorating BSG was weighed and aseptically transferred into the first test tube of 1 in 10 dilutions containing sterile distilled water as diluent. The pour plate technique as previously described by [5] was used for the primary isolation of the cellulase producing strains. Pure cultures were obtained by sub-culturing the primary plates to obtain discrete colonies.

\subsection{Biochemical Characterization and Identification}

The bacterial strains with high cellulase producing ability were picked for identification and further investigation. Preliminary identification by morphological analysis was conducted by using light microscope after Gram staining, and spore staining. The Gram staining and spore staining method have been previously described [6]. Biochemical characterization was carried out on the isolates using Analytical Profile Index (API) kits for Bacillus.

\section{Screening for Hyper Producers of Cellulase}

A total of 21 strains of bacteria strains were obtained from deteriorating Brewers Spent Grain. Therefore, a preliminary qualitative analysis for cellulolytic activity was conducted by using Congo red dye. The bacteria were grown on Carboxymethyl Cellulose (CMC) agar which was prepared by adding 5\% CMC into Nutrient Agar (Oxoid). The detailed screening procedure has been previously described [5].

\section{Determination of Protein Content of the Crude Cellulase}

Protein content of the enzyme extracts were determined by following the method of Lowry and colleagues [7] with Bovine serum albumin as standard. Protein extract, $0.2 \mathrm{ml}$ was measured into tubes and $0.8 \mathrm{ml}$ distilled 
water was added to it. Distilled water was used as blank while BSA standard curve was equally set up. In addition, $5.0 \mathrm{ml}$ of alkaline solution was added to all the tubes, mixed thoroughly and allowed to stand for $10 \mathrm{mins}, 0.5 \mathrm{ml}$ of folin-ciocalteau solution (Phenol Reagent) was added to all the test tubes and left for 30 mins after which the optical density was read at $600 \mathrm{~nm}$ wavelength in a spectrophotometer (T70 PG Instrument UV model). The protein concentration was estimated using values extrapolated from the standard graph of protein.

$$
\text { PROTEIN CONTENT }=\frac{\text { ABSORBANCE }}{\text { GRADIENT }}
$$

\section{Determination of Crude Cellulase Activity}

The activity of crude cellulase in the centrifugal supernatant was determined according to the methods which had also been previously reported by [8] [9]. Aliquots of appropriately diluted centrifugal supernatant as enzyme source was added to $50 \mathrm{mg}$ of Whatman No. 1 filter paper strip immersed in $1 \mathrm{~mL}$ of $0.05 \mathrm{M}$ sodium citrate buffer, pH 5.0. After incubation at $50^{\circ} \mathrm{C}$ for $30 \mathrm{~min}$, the reducing sugar released was estimated by the Dinitro Salicyclic Acid (DNSA) methods [10] [11]. One unit of filter paper (FPU) activity was defined as the amount of enzyme releasing $1 \mu$ mole of reducing sugar.

\section{Determination of Specific Activity}

This is the activity of an enzyme per milligram of total protein (expressed in units $/ \mathrm{mg} / \mathrm{ml}$ ). Specific activity of the cellulase was determined using the formula below.

$$
\text { SPECIFIC ACTIVITY }=\frac{\text { CRUDE ACTIVITY }(\text { Units })}{\text { PROTEIN CONTENT }(\mathrm{Mg} / \mathrm{Ml})}
$$

\section{Determination of Effect of Temperature on the Activity of Cellulase}

The Enzyme activity was measured by treating the enzyme-substrate mixture at various temperatures from $30^{\circ} \mathrm{C}$ and $80^{\circ} \mathrm{C}$. Technically, the cellulase enzyme was diluted, and $0.5 \mathrm{ml}$ of the cellulase diluted cellulase was gently pipetted into well-labelled test tubes previously loaded with 0.5 gram of shredded filter paper. The enzyme- substrate reaction was incubated at $40^{\circ} \mathrm{C}$ for 60 Minutes. In addition, other tubes prepared in this way were labelled, and each incubated at different temperatures $\left(50^{\circ} \mathrm{C}, 60^{\circ} \mathrm{C}, 70^{\circ} \mathrm{C}\right.$, and $\left.80^{\circ} \mathrm{C}\right)$ for 60 minutes in each case. Dinitro salicyclic acid (30 mls) was added into all the tubes to stop the reaction. The tubes were boiled further for 5 minutes at $100^{\circ} \mathrm{C}$ to develop the red/orange colour. On cooling down to at least temperature of $10^{\circ} \mathrm{C}, 0.2 \mathrm{ml}$ of the boiled enzyme-substrate mixture was transferred into the curvette of a spectrophotometer (UN-ICAM) and absorbance read at $540 \mathrm{~nm}$ wavelength. This DNSA method has been previously used and reported [5] [10] [11].

\section{Determination of Effect of $\mathrm{pH}$ on the Activity of Cellulase}

The activity of the cellulase was measured at various $\mathrm{pH}$ using different $\mathrm{pH}$ values of citrate buffer. Technically, $0.5 \mathrm{ml}$ of the citrate buffer at different $\mathrm{pH}(4-8)$ was mixed with $0.5 \mathrm{ml}$ of the diluted enzyme in a well labelled test tube containing filter paper strip. The assay was done with DNSA method, and water bath incubation was carried out at $50^{\circ} \mathrm{C}$ (optimum temperature).

\section{Determination of Effect of Metallic Ions on the Activity of Cellulase}

The reaction of the enzyme and filter paper substrate was allowed to proceed at $50^{\circ} \mathrm{C}$ with duplicate test tubes containing $10 \mathrm{mM} \mathrm{MnSO}_{4}, \mathrm{CaSO}_{4}, \mathrm{MnSO}_{4}, \mathrm{ZnSO}_{4}$, and $\mathrm{FeSO}_{4}$. Test tubes were labelled according to the source of carbon (BSG and Crystalline Cellulose), and above mentioned salts. The cellulase extract was diluted accordingly, and $0.5 \mathrm{ml}$ of the diluted enzyme was pipetted into the labelled test tube already loaded with 0.5 gram of shredded filter paper. Thereafter, $0.5 \mathrm{ml}$ of $10 \mathrm{mM}$ solution of each of the above mentioned salts (one salt to one test tube) was pipetted to a test tube. The incubation of the reaction mixture was done at $50^{\circ} \mathrm{C}$, and the assay done using previously described DNSA Method [5]. Tubes containing distilled water and substrates (without the enzyme) but treated in the same way as sample served as the blank. 


\section{Results and Discussion}

The crude activity of crude cellulase from Bacillus species on utilization of cellulase from Brewers Spent Grain and from crystalline cellulose was studied at different hours of fermentation. The crude cellulase activities as cellulase from BSG was observed as 239 Units, 1460OU, 13930U, 13260U, 128320U and 13650U at 0, $24 \mathrm{~h}$, 48 h, 72 h, 96 h and 120 hours respectively. The crude cellulase activities when crystalline cellulase was used as carbon source were 153U, 11757U, 12110U, 13015U, 13015U, 13850U, and 135000U at 0 h, 24 h, 48 h, 72 h, $96 \mathrm{~h}$, and $120 \mathrm{~h}$ respectively (Table 1). Statistical analyses of Variance (ANOVA) showed that the crude cellulase activity when BSG cellulose was the source of carbon was higher than cellulase activity when crystalline cellulose was used as sole carbon source. This is probably because bacillus strain used in this study had more access to crystalline cellulose than BSG celulase at the $24^{\text {th }}, 48^{\text {th }}$ hour whereas the reverse was the case at $96^{\text {th }}$ hour of fermentation (Table 1 ).

There are extensive reports of cellulose with activity of $3.69 \mathrm{FPU} / \mathrm{ml}$ produced by solid state fermentation of defatted palm kernel cake by Bacillus cereus [12].

The protein content of the crude cellulase from BSG Cellulose Erlenmeyer flask was $3.3 \mathrm{Mg} / \mathrm{ml}$ on the zero hour but increased progressively to $10.4 \mathrm{mg} / \mathrm{ml}$ on the $48^{\text {th }}$ hour. In addition, a slight decrease at 72 hour from $8.2 \mathrm{mg} / \mathrm{ml}$ to $5.97 \mathrm{Mg} / \mathrm{ml}$ on the 120 hour was also observed (Table 2). In the Erlenmayer flasks containing crystalline cellulose as carbon source, the protein content at zero hour, 24 h, 48 h, 72 h, 96 h and 12 h were 1.5 $\mathrm{mg} / \mathrm{ml}, 5.10 \mathrm{mg} / \mathrm{ml}, 6.57 \mathrm{mg} / \mathrm{ml}, 7.11 \mathrm{mg} / \mathrm{ml}, 6.0 \mathrm{mg} / \mathrm{ml}$ and $2.63 \mathrm{Mg} / \mathrm{ml}$ respectively (Table 3). The highest protein content for the BSG cellulose set-up was observed at $48 \mathrm{~h}$, and this correlates positively with the highest crude cellulase activity at the 48 hour. Similarly, for crystalline cellulase set-up, protein content was highest $(7.11 \mathrm{Mg} / \mathrm{ml})$ at 72 hour. This also correlates positively with the cellulase activity at 72 hour.

The specific enzyme activity when supplemented with BSG cellulase at Zero hour, 24 h, 48 h, 72 h, 96 h and 120 h was 182 U/Mg/ml, 1609 U, 13339, 1617.1 U/Mg/ml, 2746.6 U/Mg/ml and 2746.6 U/Mg/ml respectively. The specific cellulase activity on utilisation of crystalline cellulose as sole carbon source was $97.60 \mathrm{U} / \mathrm{Mg} / \mathrm{ml}$, 1567.1 Mg/ml, 1843.2 U/Mg/ml, 2135.3 U/mg/ml, 2308.3 U/mg/ml and 5133.1 U/Mg/ml respectively (Table 2).

Table 1. Crude activities of cellulase from Brewers Spent Grain (BSG).

\begin{tabular}{ccc}
\hline $\begin{array}{c}\text { Hours of } \\
\text { incubation }\end{array}$ & $\begin{array}{c}\text { CRUDE CELLULASE ACTIVITIES (Units) } \\
\text { BSG } \pm \text { S.D }\end{array}$ & $\begin{array}{c}\text { CRUDE CELLULASE ACTIVITIES (Units) } \\
\text { CELL } \pm \text { S.D }\end{array}$ \\
\hline 0 & $239 \pm 0.34^{\mathrm{a}}$ & $153 \pm 0.12^{\mathrm{b}}$ \\
24 & $14600 \pm 2.17^{\mathrm{a}}$ & $11757 \pm 2.56^{\mathrm{b}}$ \\
48 & $13930 \pm 2.43^{\mathrm{a}}$ & $12110 \pm 3.00^{\mathrm{b}}$ \\
72 & $13260 \pm 3.21^{\mathrm{a}}$ & $13015 \pm 2.05^{\mathrm{a}}$ \\
96 & $12832 \pm 2.45^{\mathrm{a}}$ & $13850 \pm 2.89^{\mathrm{b}}$ \\
120 & $13650 \pm 2.34^{\mathrm{a}}$ & $13500 \pm 2.12^{\mathrm{a}}$ \\
\hline
\end{tabular}

Carbon sources include; Brewers Spent Grains (BSG), and Crystalline Cellulose Powder; Values are average duplicate readings, S.D; Standard Deviation. Means followed by the same letter in a column are not significantly different $(\mathrm{p}<0.05)$.

Table 2. Protein content and specific activities of crude cellulase at different hours of incubation.

\begin{tabular}{|c|c|c|c|c|}
\hline \multirow{2}{*}{$\begin{array}{c}\text { HOURS } \\
0\end{array}$} & \multirow{2}{*}{$\begin{array}{c}\text { PROTIEN CONTENT } \\
\text { BSG + S.D } \\
3.33 \pm 0.45^{\mathrm{a}}\end{array}$} & \multirow{2}{*}{$\begin{array}{c}(\mathrm{mg} / \mathrm{ml}) \\
\text { CELL + S.D } \\
1.57 \pm 0.91^{\mathrm{b}}\end{array}$} & \multicolumn{2}{|c|}{$\begin{array}{l}\text { SPECIFIC ACTIVITIES }(\mathrm{u} / \mathrm{mg} / \mathrm{ml}) \\
\text { BSG + S.D CELL + S.D }\end{array}$} \\
\hline & & & $182.0 \pm 0.56^{\mathrm{a}}$ & $97.60 \pm 0.45^{\mathrm{b}}$ \\
\hline 24 & $9.07 \pm 1.98^{\mathrm{a}}$ & $5.10 \pm 1.46^{\mathrm{b}}$ & $1609.7 \pm 2.89^{\mathrm{a}}$ & $1567.1 \pm 4.6^{\mathrm{b}}$ \\
\hline 48 & $10.4 \pm 1.03^{\mathrm{a}}$ & $6.57 \pm 1.87^{\mathrm{b}}$ & $13339.4 \pm 6.04^{\mathrm{a}}$ & $1843.2 \pm 4.7^{\mathrm{b}}$ \\
\hline 72 & $8.2 \pm 1.11^{\mathrm{a}}$ & $7.11 \pm 1.56^{\mathrm{a}}$ & $1617.1 \pm 4.23^{\mathrm{a}}$ & $2135.3 \pm 4.8^{\mathrm{ab}}$ \\
\hline 92 & $6.67 \pm 1.34^{\mathrm{a}}$ & $6.0 \pm 1.56^{\mathrm{a}}$ & $2746.6 \pm 4.19^{\mathrm{a}}$ & $2308.3 \pm 5.2^{\mathrm{ab}}$ \\
\hline 120 & $5.97 \pm 1.15^{\mathrm{a}}$ & $2.63 \pm 1.06^{\mathrm{b}}$ & $2286.4 \pm 6.00^{\mathrm{a}}$ & $5133.1 \pm 6.7^{\mathrm{b}}$ \\
\hline
\end{tabular}

S. D; Standard deviation. Values are average of duplicate readings, BSG; Brewers Spent Grain. Means followed by the same letter in a column are not significantly different $(\mathrm{p}<0.05)$. 
Table 3. Effect of temperature on cellulase activity.

\begin{tabular}{cccccc}
\hline $\begin{array}{c}\text { Carbon } \\
\text { source/hour of } \\
\text { incubation }\end{array}$ & $30 \pm$ S.D & $40 \pm$ S.D & $60 \pm$ S.D & $70 \pm$ S.D & $80 \pm$ S.D \\
\cline { 2 - 6 } BSG/0 HR & NS & NS & NS & NS & NS \\
CELL/0 HR & NS & NS & NS & NS & NS \\
BSG/24 HR & $2024.28 \pm 3.61^{\mathrm{a}}$ & $1518.21 \pm 2.10^{\mathrm{a}}$ & $519.16 \pm 0.19^{\mathrm{a}}$ & $1134.30 \pm 0.26^{\mathrm{a}}$ & $397.00 \pm 0.01^{\mathrm{a}}$ \\
CELL/24 HRS & $1986.75 \pm 3.06^{\mathrm{b}}$ & $1489.56 \pm 2.10^{\mathrm{a}}$ & $487.99 \pm 0.26^{\mathrm{a}}$ & $1134.30 \pm 0.26^{\mathrm{a}}$ & $349.00 \pm 0.11^{\mathrm{a}}$ \\
BSG/48 HRS & $1605.61 \pm 2.79^{\mathrm{ab}}$ & $1316.6 \pm 2.96^{\mathrm{b}}$ & $441.40 \pm 0.47^{\mathrm{a}}$ & $1301.23 \pm 2.4^{\mathrm{b}}$ & $570.71 \pm 0.03^{\mathrm{b}}$ \\
CELL/48 HRS & $2656.03 \pm 2.79^{\mathrm{c}}$ & $1728.53 \pm 1.14^{\mathrm{ab}}$ & $878.56 \pm 0.86^{\mathrm{b}}$ & $1156.37 \pm 0.97^{\mathrm{a}}$ & $963.01 \pm 0.26^{\mathrm{ab}}$ \\
BSG/72 HRS & $2046.03 \pm 3.19^{\mathrm{a}}$ & $1351.15 \pm 1.09^{\mathrm{b}}$ & $410.17 \pm 0.26^{\mathrm{a}}$ & $1299.93 \pm 0.96^{\mathrm{a}}$ & $738.31 \pm 0.14 \mathrm{ab}^{\mathrm{ab}}$ \\
CELL/72 HRS & $2301.32 \pm 3.69^{\mathrm{c}}$ & $2533.11 \pm 3.61^{\mathrm{c}}$ & $634.66 \pm 0.03^{\mathrm{ab}}$ & $1456.95 \pm 0.96^{\mathrm{b}}$ & $1473.31 \pm 0.14^{\mathrm{c}}$ \\
BSG/96 HRS & $2764.52 \pm 2.87^{\mathrm{cd}}$ & $2645.88 \pm 3.14^{\mathrm{c}}$ & $842.41 \pm 0.03^{\mathrm{b}}$ & $1898.39 \pm 1.12^{\mathrm{ab}}$ & $771.22 \pm 0.39^{\mathrm{ab}}$ \\
CELL/96 HRS & $3007.28 \pm 3.87^{\mathrm{d}}$ & $2578.61 \pm 2.86^{\mathrm{c}}$ & $1206.87 \pm 0.12^{\mathrm{c}}$ & $1569.59 \pm 0.06^{\mathrm{ab}}$ & $903.50 \pm 0.33^{\mathrm{ab}}$ \\
BSG/120 HRS & $2850.06 \pm 1.06^{\mathrm{cd}}$ & $2545.17 \pm 2.87^{\mathrm{c}}$ & $742.34 \pm 0.14^{\mathrm{b}}$ & $2021.56 \pm 0.18^{\mathrm{c}}$ & $881.53 \pm 0.46^{\mathrm{ab}}$ \\
CELL/12O HRS & $7567.85 \pm 1.79^{\mathrm{e}}$ & $6168.63 \pm 3.07^{\mathrm{d}}$ & $212.40 \pm 0.06^{\mathrm{a}}$ & $2482.50 \pm 0.28^{\mathrm{cd}}$ & $1579.77 \pm 0.11^{\mathrm{c}}$ \\
\hline
\end{tabular}

NS; Not studied. CELL; crystalline cellulose powder, BSG; cellulose from brewers spent grain. Values are units of enzyme/cellulase. Means followed by the same letter in the column are not significantly different $(\mathrm{p}<0.05)$ (Duncan multiple range test).

Generally, the specific activity of cellulase produced from crystalline cellulase was highest at 5133.1 U/Mg/ $\mathrm{ml}$ on the 120 hour of fermentation as against a specific activity of $2286.4 \mathrm{U} / \mathrm{Mg} / \mathrm{ml}$ on the 120 hour of fermentation. This significantly higher specific activity of the crystalline cellulose could be because the crystalline cellulose is more refined than the crude BSG cellulose.

Studies on cellulase produced by wild strains of Aspergillus niger, Penicillium chryseogenum, and Trichoderma harzianum using a submerged fermentation method recorded a maximum activities of $0.30,0.24$ and 0.20 Units/Mg protein for cellulase from A. niger, P. chryseogenum, and T. harzianum respectively at 144 hours of incubation using Saw dust as substrate [13].

In another related study, a novel thermo-tolerant endoglucanase from Bacillus strains with the highest specific activity of 1.1 U/Mg proteins on utilisation of 8\% carboxymethyl cellulose was reported [14].

The temperature tolerance properties of the Bacillus cellulase were also studied at different time intervals with respect to the source of cellulose. The temperature studies were not carried on cellulase harvested on the zero hour because activity was grossly low. Cellulase activities in both sources of cellulose (BSG and crystalline cellulose) were high on incubation of enzyme and substrate at $30^{\circ} \mathrm{C}$ The BSG and crystalline cellulose options had activities of 2850.06 and 6168.63 Units respectively (Table 3). Generally, for both sources of carbon at $60^{\circ} \mathrm{C}$, and $80^{\circ} \mathrm{C}$ activities dropped down significantly while at $70^{\circ} \mathrm{C}$ the activities were between 113.3 units to 2482.50 units (Table 3). Thus it is hereby established that temperatures of $30^{\circ} \mathrm{C}$ and $40^{\circ} \mathrm{C}$ were optimum temperatures for cellulase activity of Bacillus species (Strain B223) cellulase.

There are several studies on tolerance of cellulase to different temperature. The study reported the production of cellulase by a cellulolytic bacterium identified as Cellulomonas sp ASN2, with an optimum temperature of $60^{\circ} \mathrm{C}[15]$.

There are studies on cellulase from microorganisms associated with the gut of giant African snail (Archachatina marginata) [4]. It was documented that a cellulase activity of $0.62 \mathrm{Mg} / \mathrm{ml} / \mathrm{sec}$ and optimum $\mathrm{pH} 80^{\circ} \mathrm{C}$ for Bacillus subtilis cellulase. Similarly, other reports showed a minimum and maxmum activity of $45^{\circ} \mathrm{C}$ and $40^{\circ} \mathrm{C}$ respectively of cellulase produced by Bacillus subtilis [16].

The effect of various $\mathrm{pH}$ on the activities of cellulase was also studied and reported. $\mathrm{pH}$ was varied between 3.0 and 8.0 for both cellulase produced using BSG cellulose and refined cellulose powder, and the optimum pH was observed at 5.0. This implies that the catalysis mediated by cellulase of B223 strain is best achieved at $\mathrm{pH}$ 5.0 (Table 4).

The optimum $\mathrm{pH}$ of 5.0, and 5.5 for cellulase produced from Penicillium artrovenetum in a submerged fermentation condition was documented by other workers [17]. In another related study, it was established that a bacteria cellulase had its optimum activity at a pH of 7.5 [18]. This alkaline $\mathrm{pH}$ or near neutral pH condition did 
Table 4. Effect of $\mathrm{pH}$ on the activities of cellulase of different hours of production and different carbon sources.

\begin{tabular}{cccccccc}
\hline $\begin{array}{c}\text { Carbon } \\
\text { source/hour of } \\
\text { incubation }\end{array}$ & $3.0 \pm$ S.D & $4.0 \pm$ S.D & $4.8 \pm$ S.D & $5.0 \pm$ S.D & $6.0 \pm$ S.D & $7.0 \pm$ S.D & $8.0 \pm$ S.D \\
\cline { 2 - 8 } BSG/0 HRS & NS & NS & NS & NS & NS & NS & NS \\
CELL/0 HRS & NS & NS & NS & NS & NS & NS & NS \\
BSG/24 HRS & $135.24 \pm 0.11^{\mathrm{a}}$ & $287.94 \pm 0.19^{\mathrm{b}}$ & $1605.47 \pm 0.26^{\mathrm{b}}$ & $1112.48 \pm 0.32^{\mathrm{a}}$ & $889.99 \pm 2.40^{\mathrm{a}}$ & $1269.54 \pm 0.91^{\mathrm{a}}$ & $397.00 \pm 0.26^{\mathrm{a}}$ \\
CELL/24 HRS & $129.47 \pm 0.46^{\mathrm{a}}$ & $119.60 \pm 0.26^{\mathrm{a}}$ & $1780.00 \pm 0.27^{\mathrm{b}}$ & $1162.47 \pm 0.46^{\mathrm{a}}$ & $804.00 \pm 2.61^{\mathrm{a}}$ & $1280.71 \pm 0.94^{\mathrm{a}}$ & $392.00 \pm 0.11^{\mathrm{a}}$ \\
BSG/48 HRS & $163.60 \pm 0.26^{\mathrm{a}}$ & $95.12 \pm 0.81^{\mathrm{a}}$ & $1340.24 \pm 0.81^{\mathrm{a}}$ & $1008.26 \pm 0.27^{\mathrm{a}}$ & $939.78 \pm 0.23^{\mathrm{a}}$ & $528.86 \pm 0.60^{\mathrm{b}}$ & $570.71 \pm 0.19^{\mathrm{b}}$ \\
CELL/48 HRS & $66.25 \pm 0.27^{\mathrm{b}}$ & $96.36 \pm 0.03^{\mathrm{a}}$ & $1842.96 \pm 0.03^{\mathrm{c}}$ & $1915.24 \pm 0.21^{\mathrm{b}}$ & $1403.30 \pm 0.26^{\mathrm{b}}$ & $1247.24 \pm 0.67^{\mathrm{a}}$ & $963.64 \pm 0.29^{\mathrm{ab}}$ \\
BSG/72 HRS & $231.63 \pm 0.47^{\mathrm{ab}}$ & $453.60 \pm 0.37^{\mathrm{c}}$ & $1616.56 \pm 0.47^{\mathrm{b}}$ & $1307.72 \pm 0.04^{\mathrm{ab}}$ & $926.50 \pm 0.28^{\mathrm{a}}$ & $1143.65 \pm 0.21^{\mathrm{a}}$ & $738.31 \pm 0.84^{\mathrm{ab}}$ \\
CELL/72 HRS & $93.82 \pm 0.29^{\mathrm{b}}$ & $419.43 \pm 0.29^{\mathrm{c}}$ & $2135.76 \pm 2.61^{\mathrm{d}}$ & $1782.56 \pm 0.32^{\mathrm{b}}$ & $1716.33 \pm 0.80^{\mathrm{c}}$ & $1335.54 \pm 0.26^{\mathrm{ab}}$ & $1473.51 \pm 0.30^{\mathrm{c}}$ \\
BSG/96 HRS & $563.58 \pm 0.28 \mathrm{c}$ & $337.14 \pm 0.07^{\mathrm{ab}}$ & $2746.23 \pm 2.09 d^{\mathrm{e}}$ & $2295.03 \pm 0.33^{\mathrm{c}}$ & $2046.70 \pm 0.80 b^{\mathrm{c}}$ & $1874.66 \pm 0.03^{\mathrm{c}}$ & $771.22 \pm 0.30^{\mathrm{ab}}$ \\
CELL/96 HRS & $1490.4 \pm 0.14^{\mathrm{d}}$ & $316.56 \pm 0.06^{\mathrm{ab}}$ & $2308.22 \pm 0.26^{\mathrm{d}}$ & $2499.47 \pm 0.26^{\mathrm{c}}$ & $1503.64 \pm 2.49^{\mathrm{b}}$ & $1147.52 \pm 0.34^{\mathrm{a}}$ & $903.50 \pm 0.36^{\mathrm{ab}}$ \\
BSG/120 HRS & $391.06 \pm 0.11^{\mathrm{ab}}$ & $490.48 \pm 0.27 \mathrm{c}$ & $2286.68 \pm 0.41^{\mathrm{d}}$ & $1855.86 \pm 0.85^{\mathrm{b}}$ & $1252.70 \pm 2.69^{\mathrm{b}}$ & $1663.64 \pm 0.26^{\mathrm{c}}$ & $881.53 \pm 0.14^{\mathrm{ab}}$ \\
CELL/120 HRS & $2437.36 \pm 0.03^{\mathrm{e}}$ & $646.95 \pm 0.84^{\mathrm{d}}$ & $5115.45 \pm 0.47^{\mathrm{f}}$ & $5025.17 \pm 0.91^{\mathrm{d}}$ & $2828.54 \pm 2.80^{\mathrm{d}}$ & $5055.26 \pm 3.15^{\mathrm{d}}$ & $1579.77 \pm 2.97^{\mathrm{c}}$ \\
\hline
\end{tabular}

Means followed by the same letter in the column are not significantly different $(\mathrm{p}<0.05)$ (Duncan multiple range test). Values are units of cellulase.

Table 5. Effect of metallic ions on the activities of cellulase produced through submerged fermentation at 96 hour of fermentation.

\begin{tabular}{|c|c|c|c|c|}
\hline \multirow[t]{2}{*}{ Metal Ions (10 mM) } & \multicolumn{2}{|c|}{$\begin{array}{l}\text { CELLULASE ACTIVITIES BEFORE } \\
\text { EXPOSURE TO METALS (U/Mg/Ml) }\end{array}$} & \multicolumn{2}{|c|}{$\begin{array}{l}\text { CELLULASE ACTIVITIES BEFORE AFTER TO } \\
\text { METALS (U/Mg/Ml) }\end{array}$} \\
\hline & $\mathrm{BSG} \pm \mathrm{S} . \mathrm{D}$ & CELL \pm S.D & $\mathrm{BSG} \pm \mathrm{S} . \mathrm{D}$ & CELL \pm S.D \\
\hline $\mathrm{CU}$ & $2746.60 \pm 0.31^{\mathrm{a}}$ & $2308.03 \pm 0.06^{\mathrm{a}}$ & $1382.26 \pm 0.94^{\mathrm{b}}$ & $1378.34 \pm 0.81^{\mathrm{ab}}$ \\
\hline $\mathrm{Fe}$ & $2746.60 \pm 0.26^{\mathrm{a}}$ & $2308.03 \pm 0.04^{\mathrm{a}}$ & $1542.44 \pm 0.97^{\mathrm{ab}}$ & $3719.53 \pm 0.92^{c}$ \\
\hline $\mathrm{Mn}$ & $2746.60 \pm 0.27^{\mathrm{a}}$ & $2308.03 \pm 0.21^{\mathrm{a}}$ & $4763.76 \pm 0.62^{\mathrm{c}}$ & $5599.08 \pm 0.03^{\mathrm{d}}$ \\
\hline $\mathrm{Zn}$ & $2746.60 \pm 0.41^{\mathrm{a}}$ & $2308.03 \pm 0.09^{\mathrm{a}}$ & $1038.18 \pm 0.06^{\mathrm{a}}$ & $1193.68 \pm 0.26^{\mathrm{a}}$ \\
\hline $\mathrm{Mg}$ & $2746.60 \pm 0.03^{\mathrm{a}}$ & $2308.03 \pm 0.37^{\mathrm{a}}$ & $1506.84 \pm 0.08^{\mathrm{ab}}$ & $1503.64 \pm 0.01^{\mathrm{ab}}$ \\
\hline
\end{tabular}

Means followed by the same letter in the column are not significantly different $(\mathrm{p}<0.05)$ (Duncan multiple range test).

not tally with the optimum pH of the B223 Bacillus cellulase produced by submerged fermentation of cellulose abundant Brewers Spent Grain (BSG).

In addition, the effect of metallic ions on the B223 cellulase was investigated. Heavy metals such as copper reduced the specific activity of cellulase from 2746.60 to $1382.62 \mathrm{U} / \mathrm{Mg} / \mathrm{ml}$. Iron, Zinc and magnesium reduced the specific activity of the cellulase (Table 5). These are heavy metals except magnesium, and their inhibitory mechanism could be that they bind initially to active site before substrate thus reducing the chances of substrate binding. This establishes a competitive inhibition between substrate and metallic ions for the active site of the enzyme.

On the contrary, manganese at $10 \mathrm{mM}$ concentration was able to increase the B223 cellulase activity from 2746.60 to 4763.76 and 2308.03 to $5599.08 \mathrm{U} / \mathrm{Mg} / \mathrm{ml}$ for BSG cellulose and crystalline cellulose options respectively (Table 5). This implies that manganese impacts over $90 \%$ increase on activities of cellulase from $\mathrm{Ba}$ cillus species strain B223. Thus the manganese ion acts as a co-factor for B223 cellulase. In a related report, it was shown that a cellulase enzyme from Cellulomonas was stimulated by $\mathrm{Co}^{2+}$ and $\mathrm{Mn}^{2+}$ while $\mathrm{Hg}^{2+}$ and $\mathrm{Fe}^{2+}$ reduced its activity [18].

Only two sources of carbon were tried in this experiment. Results obtained showed that there is no statistical significance between the experimental group that contained refined crystalline cellulose and Cellulose from Brewers' Spent Grain. This by implication shows that the crude Brewers' Spent Grain is a good raw material, and if refined further can as well provide more cellulose to organisms carrying out fermentation than the refined crystalline cellulose. This is the right time for Nigerian Government to pay adequate research attention to research 
and development in agro-allied processing.

\section{Conclusion}

The production of cellulase using cellulose from BSG is established, and the possibility of packaging of B223 cellulase by incorporating manganese ion as co-factor is hereby established in this study. This local production of cellulase from local sources is a noteworthy contribution as it reduces enzyme cost, cost of final product, increases Gross Domestic Products (GDP), and saves foreign exchange.

\section{References}

[1] Apun, K. (1995) Lecture Notes on Cellulase Production. National Centre for Biotechnology Education, London.

[2] Khan, J.A. and Singh, S.K. (2011) Production of Cellulase Using Cheap Substrates by Solid State Fermentation. International Journal of Plant, Animal and Environmental Sciences, 1, 179-187.

[3] Pandit, N.P. and Maheshwari, S.K. (2012) Optimization of Cellulase Enzyme Production from Sugarcane Pressmud Using Oyster Mushroom-Pleurotus Sajor-Caju by Solid State Fermentation. Journal of Bioremediation and Biodegradation, 1-5.

[4] Oyeleke, S.B., Oyewole, O.A., Egwim, E.C., Dauda, B.E.N. and Ibeh, E.N. (2012) Cellulase and Pectinase Production Potentials of Aspergillus niger Isolated from Corn Cob. Bayero Journal of Pure and Applied Sciences, 5, 78-83. http://dx.doi.org/10.4314/bajopas.v5i1.15

[5] Orji, F.A., Dike, E.N., Lawal, A.K., Elemo, G.N., Olatope, S.O.A., Famotemi, A.C., Itoandoan, E.E., Suberu, Y.L., Asieba, G.O., Sadiq, A.O., Olasore, O., Okafor, E.N. Ugbana, A.I. and Adefiranye, A.O. (2013) Production of Cellulase from Bacillus Species Using Cellulose from Brewers Spent Grain (BSG) as Sole Carbon Source. Asian Journal of Microbiology, Biotechnology, and Environmental Sciences, 15, 839-848.

[6] Kanu and Okereke (2004) Characterization and Identification of Microorganisms. In: Onyeagba, A., Ed., Laboratory Guide in Microbiology, Crystal Publishers, Okigwe, 379.

[7] Lowry, O.H., Rosenbrough, N.J., Farr, A. and Randall, R.J. (1951) Protein Measurement with the Folin Phenol Reagent. Journal of Biological Chemistry, 193, 265-275.

[8] Mandels, M., Andreotti, R. and Roche, C. (1976) Measurement of Saccharifying Cellulase. Biotechnol Bioeng Symp, 6, 21-33.

[9] Kumar, R., Gaurav, M., Balan, V. and Wyman, C.E. (2009) Physical and Chemical Characterization of Corn Stovar and Poplar Solids Resulting from Leading Pretreatment Technologies. Bioresource Technology, 100, 3948-3962. http://dx.doi.org/10.1016/j.biortech.2009.01.075

[10] Miller, G. (1948) Use of Dinitrosalicyclic Acid Reagent for Determination of Reducing Sugar. The Journal of Biological Chemistry, 714, 961-967.

[11] Akinola, S.O., Kuboye, A.O. and Olatuji, O. (2004) Use of Fungal Pectinase for Clarification of Guava Juice. Nigerian Journal of Microbiology, 18, 293-296.

[12] Lah, T.N.T., Rahman, N.N.N. and Nama, M.M.B. (2012) Cellulase Activity and Glucose Production by Bacillus Cereus Monoculture and Co-Culture Utilizing Palm Kernel Cake (PKC) under Solid State Fermentation. International Conference on Environment, Energy and Biotechnology, Singapore, 33, 172-177.

[13] Chinedu, S.N., Okochi, V.I. and Omidiji, O. (2011) Cellulase Production by Wild Strains of Aspergillus niger, Penicillium chrysogenum and Trichoderma harzianum Grown on Waste Cellulosic Materials. Ife Journal of Science, 13, 57-62.

[14] Sadhu, S., Saha, P., Sen, S.K. and Maiti, T.K. (2013) Production, Purification and Characterization of a Novel Thermotolerant Endoglucanase (CMCase) from Bacillus Strain Isolated from Cow Dung. SpringerPlus, 2, 1-10.

[15] Odeniyi, O.A., Onilude, A.A. and Ayodele, M.A. (2009) Production Characteristics and Properties of Cellulase/ Polygalacturonase by a Bacillus Coagulans Strain from a Fermenting Palm-Fruit Industrial Residue. African Journal of Microbiology Research, 3, 407-417.

[16] Ray, A.K., Bairagi, A., Ghosh, K.S. and Sen, S.K. (2007) Optimization of Fermentation Conditions for Cellulase Production by Bacillus subtilis CY5 and Bacillus circulans TP3 Isolated from Fish Gut. Acta Ichthyologica et Piscatoria, 37, 47-53. http://dx.doi.org/10.3750/AIP2007.37.1.07

[17] Adeleke, A.J., Odunfa, S.A., Olanbiwonninu, A. and Owoseni. M.C. (2012) Production of Cellulase and Pectinase from Orange Peels by Fungi. Nature and Science, 10, 107-112.

[18] Irfan, M., Safdar, A., Syed, Q. and Nadeem, M (2012) Isolation and Screening of Cellulolytic Bacteria from Soil and Optimization of Cellulase Production and Activity. Turkish Journal of Biochemistry, 37, 287-293.

http://dx.doi.org/10.5505/tjb.2012.09709 